\title{
ATENÇÃO À BARBÁRIE: ELUCIDAÇÃO DAS DETERMINAÇÕES DA MATERIALIDADE COMO PERCURSO
}

\author{
Renata Lucia Baptista Flores ${ }^{1}$
}

\begin{abstract}
EVANGELISTA, O.; SEKI, A.K. (Orgs.). Formação de professores no Brasil: leituras a contrapelo. Araraquara: Junqueira\&Marin, 2017. 280p.

"O materialista histórico os contempla [os bens culturais] com distanciamento.
\end{abstract} Pois todos os bens culturais que ele vê têm uma origem sobre a qual ele não pode refletir sem horror."

(Walter Benjamin, 1994).

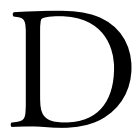

e uns tempos para cá, em setores críticos, parece haver algum consenso em torno da ideia de que a realidade que nos cerca é de barbárie. Na era da comunicação "em tempo real”, on-line, via redes sociais, há significativo volume de apontamentos tanto de barbaridades quanto sobre aqueles(as) que as cometem. Ocorre, porém, que, para lidar com tal nível de degeneração, a tarefa a ser empreendida é a da atuação para além dos posts; a demanda é do mergulho em busca do caráter essencial, e não meramente fenomênico, dessa realidade.

No universo da produção acadêmica brasileira em relação à docência e ao seu processo formativo, igualmente, pode-se dizer que essa verticalização na busca obstinada pelas determinaçóes essenciais que conformam a construçáo aparencial das políticas é dever dos(as) pesquisadores(as). E essa é a contribuição desta importante obra organizada por Olinda Evangelista e Allan Kenji Seki, da Universidade Federal de Santa Catarina (UFSC). Exatamente como anunciado, no desenvolvimento de "uma metodologia de análise documental embasada no referencial marxista” (EVANGELISTA; SEKI, 2017, p.11), a coletânea apresenta trabalhos que se dedicam a políticas educacionais no esforço de apreensão de suas determinaçóes e, ainda, evidenciando "a conexão orgânica entre seus conteúdos e as correlaçóes de forças que as produziram" (EVANGELISTA; SEKI, 2017, p. 11), configurando-se relevante material para os que estudam a área em tela compreendendo a imprescindibilidade de fazê-lo em uma perspectiva crítica.

No prefácio de José Carlos Libâneo desfruta-se do fecundo potencial reflexivo que o livro carrega: para além de apresentar a obra, seus organizadores e interlocutores, o reconhecido professor nos brinda com sínteses e reflexóes que sua leitura lhe propiciou, ressaltando, sobretudo, a lógica de fundo em que se

${ }^{1}$ Universidade Federal de Santa Catarina - Florianópolis (SC), Brasil. E-mail: renataflores2010@gmail.com DOI: 10.1590/ES0101-73302018188241 
embasam os oito diferentes artigos do livro: a educação, no capitalismo neoliberal, é uma das condiçôes necessárias para a reprodução econômica e ideológica do capital. E é na esteira dessa ideia basal que anuncia que os autores, ao longo da obra, desvelam as entranhas das estratégias largamente difundidas hoje no campo da educaçấo. Convincente chamado à entrada em cada um dos capítulos propostos.

"A tragédia docente e suas faces", o primeiro deles, é de autoria de Eneida Oto Shiroma, Maria Helena Michels, Olinda Evangelista e Rosalba Maria Cardoso Garcia, e apresenta nove faces da docência que vêm sendo gestadas com base na construída ideia da "tragédia docente": o reconvertido, o desqualificado, o avaliado, o aprendiz, o multifuncional, o responsabilizado, o massificado da Educação a Distância $(\mathrm{EaD})$, o instrumentalizado e o violentado. Além de identificar tais faces, indica a função delas na produção/garantia de manutenção da instrumentalização do professor a serviço da difusão de uma visão de mundo estreita e fragmentada, e ainda expóe a precarização do campo de trabalho com a consequente profusão de "para-professores". Não termina, contudo, sem apontar a potência do professor pensante, indicando o caminho de luta existente e pulsante.

Majoritariamente composto por produções de pesquisadores(as) do Grupo de Estudos sobre Política Educacional e Trabalho da UFSC (GEPETO/ UFSC), tem em seu segundo capítulo a única contribuição "externa". "Valorização dos professores no Plano Nacional de Educação (2014-2024): muito a ser feito pela valorização dos(as) profissionais da educação" é escrito por Cláudia Lino Piccinini e Glória de Melo Tonácio, integrantes do GT Trabalho e Formação de Professores do Coletivo de Estudos em Marxismo e Educação da Universidade Federal do Rio de Janeiro (COLEMARX/UFRJ). As interlocutoras do grupo catarinense trazem para a discussão o Plano Nacional de Educação (PNE) dos governos Lula e Dilma, focando especialmente os itens relacionados à valorização dos(as) profissionais da educação. Em sua análise, demonstram que a supostamente intentada valorização docente está relacionada a uma "qualidade educacional", que, por sua vez,se apoia em estratégias que se vinculam à intenção de geração de lucro. Revelam, enfim, sua contraditória articulação com os ataques aos salários e às carreiras docentes.

Aline Decker escreve "A formação docente no projeto político do Banco Mundial (2000-2014)", no qual problematiza o projeto político de educação e formaçáo de professores do organismo internacional na virada do século XXI por meio da análise de documentos. Indicando a circunscrição da educação a serviço do mercado, segundo a lógica do Banco Mundial, situa sua compreensão de uma formação de professores voltada ao treinamento para e na sala de aula. Municia a percepção de que a agência lança mão de estratégias de convencimento para a incorporação, pelos países, de um projeto educativo útil para a sociabilidade capitalista.

O protagonismo docente como contraface da responsabilização dos professores pelos resultados escolares, a partir do que veio a ser difundido no Brasil 
pela Rede Docente da América Latina e Caribe ligada à UNESCO-OREALC, é o cerne da discussão de Mari Celma Alves no quarto capítulo, "Rede Kipus e a construção do consenso: o protagonismo docente". Alertando para o eficiente potencial aliciador da sedutora ideia de protagonismo, a autora não deixa de sinalizar os impactos desse produzido consenso nas políticas para a formação de professores.

Com foco na formação docente para a educação especial, Maria Helena Michels e Kamille Vaz analisam o período que se seguiu à divulgação do documento Política Nacional de Educação Especial na perspectiva da Educação Inclusiva, de 2008. As autoras apontam o equívoco de se pensar nessa perspectiva apartando-a da política para a Educação Básica de modo geral,tendo em vista que compóe mudanças e adaptaçóes da escola para atender às demandas do capital. "A política da formação para os professores da educação especial: a ironia do discurso" desvela um encaminhamento direcionado à formatação do modelo desejado de professor: o multiprofissional.

O sexto capítulo, de Lêda Letro Ribeiro, dedica-se à "Formaçáo inicial do professor para a EJA" e revela, por meio do cruzamento de documentos, a articulaçáo do Aparelho de Estado com movimentos e UNESCO para educar jovens e adultos para o trabalho simples.

Aline de Souza Mandeli foca a expressiva expansão da $\mathrm{EaD}$ na formação do professor, tanto na esfera privada quanto na pública, em especial, nos governos do Partido dos Trabalhadores - PT (Lula 2003-2010 e Dilma 2011-2014). "EaD e UAB: a consolidação da fábrica de professores em nível superior" apresenta a configuração da Universidade Aberta do Brasil (UAB) como o mais significativo programa de formação inicial em $\mathrm{EaD}$. Ademais, caracteriza a instituição, estruturada na lógica do capital, como uma verdadeira "fábrica de professores", que atende à demanda de formação precária, aligeirada e instrumental.

Concluindo a coletânea, Jocemara Triches examina a reforma de cursos de Pedagogia em 27 universidades federais, após a definição das Diretrizes Curriculares Nacionais para o Curso de Graduação em Pedagogia, em 2006. "Formação docente em Cursos de Pedagogia: questóes em torno da agenda do capital"se debruça sobre os programas para trazer à tona os licenciados que as Instituiçóes Federais de Ensino Superior (IFES) pretendiam formar e o modo como internalizaram seu projeto formativo.

$\mathrm{Na}$ VII das "Teses sobre o conceito de história" desenvolvidas por Walter Benjamin, encontra-se a primorosa síntese sobre o papel do materialista histórico, precisamente a referenciada no título da obra em apreço: escovar a história a contrapelo. Alusão mais que adequada em um livro que reúne abordagens de observadores distanciados, que não se desviam dos horrores, pelo contrário, os expóem como tarefa de um tempo em que, se a razão range os dentes, intelectuais, professores e professoras problematizam "os objetivos da política de 
formação docente, sua instrumentalização para a formação da força de trabalho, sua intenção de dificultar em escala crescente as capacidades do pensamento crítico" (EVANGELISTA; SEKI, 2017, p. 12).

A barbárie na formação de professores no Brasil está posta, mas a possibilidade de conscientizaçáo acerca dos elementos que estruturam esse modus operandi do capital se mostra, mais que possível, vigorosa nesse conjunto de textos, o que caracteriza o livro, enfim, como relevante arma para a necessária resistência em tempos tão obscuros.

\section{Referência}

EVANGELISTA, O.; SEKI, A.K. (Orgs.). Formação de professores no Brasil: leituras a contrapelo. Araraquara: Junqueira \& Marin, 2017. 280 p.

Recebido em 3 de novembro de 2017.

Aceito em 15 de janeiro de 2018. 